\title{
Bacteriological Evaluation and Their Antibiotic Sensitivity Pattern in Tonsillitis
}

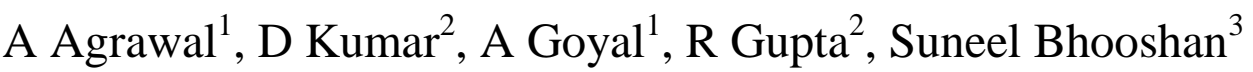 \\ 1Department of Microbiology, S. N. Medical College, Agra. India \\ 2Department of ENT, S.N.Medical College, Agra. India \\ 3Department of Microbiology, AIIMS, Bhopal M.P India
}

\begin{abstract}
The Study Was Carried Out On 140 Patients With Signs And Symptoms Of Tonsillitis.Tonsillar Swabs Were Taken And Final Evaluation Was Done On The Basis Of Standard Biochemical Test. The Antimicrobial Susceptibility Test Was Done As Per Guidelines Of CLSI.

Out Of 140 Tonsillar Surface Swab Cultures, 135 Cultures Showed Bacterial Isolates.

Staphylococcus Aureus Was The Commonest Isolate From 16 Swabs (11.43\%), Followed By Streptococcus Pneumoniae In 7 Swabs (5.00\%). The Other Isolated Bacteria Includes Pseudomonas Species, E. Coli, Beta Haemolyticstreptococci And Proteus Vulgaris.

Out Of 35 Bacterial Isolates, 30 Strains Were Found Sensitive To Netilmycin. Staphylococcus Species Showed Susceptibility Of 81.25\% With Netilmycin, 68.75\% With Gentamicin. Amoung 16 Staphylococcus Species 6 Were MRSA Which Were 100\% Sensitive To Vancomycin. Pneumococcus Species Were 100.00\% Resistant With Cefaclor, $85.71 \%$ With Gentamicin, And 71.43\% With Tobramycin.
\end{abstract}

Keywords: Antimicrobial, Bacteriology, Tonsillitis,

\section{Introduction}

The tonsils are subepithelial lymphoid collection occupied within the triangular fossa (sinus) between the palatoglossalpillar anteriorly and palatopharangeal pillar posteriorly. It is a disease of childhood but also frequently seen in adults. These contain various types of lymphocytes (mainly B types) and secrete antibodies. The neutrophils are initial active participant in bacterial infection and inflammation. The infection may occur primarily or secondarily as a result of upper respiratory tract infection, usually preceded by viral infection.

The tonsils are located particularly in areas where microorganisms are most abundantly found. They are known to permit the passage of organisms through the epithelium which may be deficient at places, into the lymphatic tissues and bear the brunt of all individual attacks of disease. Hence it is the first and foremost duty to identify the individual pathogenic organisms causing tonsillitis and in turn producing other constitutional dreadful diseases, affecting joints, heart and kidneys.

Common causative organisms isolated include Alpha-haemolyticStreptococci, Staphylococcus aureus, non-pathogenic Neisseria species, Haemophylus influenza, Pneumococcus, Enterococcus, Bacteroidsfragilis group and Corynebacterium species ${ }^{[1]}$. No anaerobes were identified. Bacterial isolates from the tonsil and adenoid were similar in number and frequency of occurrence. Three fourth patients share common pathogens in tonsil and adenoid tissue ${ }^{[2]}$

In the past, chronic tonsillitis was largely a clinical concept but today bacteriological and pathoanatomical considerations are getting more attention ${ }^{[3]}$.The reason why the patients of recurrent and chronic tonsillitis patients do not respond to antibiotics therapy is not clear. Possible reason could be due to low concentration of antibiotics in tonsillar core tissue because of scarring as a result of recurrent infection leading to less diffusion of antibiotics ${ }^{[4]}$. Recurrent tonsillitis refractory to penicillin therapy poses a major medical problem in all age group. This has been attributed to the penicillin resistant strains among the pharyngeal flora.

\section{Aims \& Objective \\ To find out the common bacterial isolates which are prevalent in the patients of tonsillitis and their antimicrobial sensitivity pattern.}

\section{Materials \& Methods}

The study was carried out on 140 patients referred from ENT OPD with signs and symptoms of tonsillitis (sore throat, fever, and difficulty in swallowing, malaise and history of recurrent upper respiratory tract infection) and submitted for bacteriological evaluation and their sensitivity to Microbiology Department at Darbhanga Medical College, Darbhanga from July 2007 to June 2008. 
Two tonsillar swabs were taken under aseptic precautions from each patient. Gram staining was performed on first swab and second swab was placed on blood agar, and MacConkeys agar. The final evaluation was done on the basis of standard biochemical tests.

Antibacterial susceptibility test was performed on Muller Hinton Agar by the Kirby Bauer disc diffusion method as per guidelines of CLSI.

\section{Results}

The commonest age group of tonsillitis is between 11-20 years where the maximum number of 57 cases $(40.72 \%)$ occurred and the minimum 12 cases $(8.57 \%)$ in age group beyond 30 years.(TABLE 1$)$

Overall there is male predominance in 80 cases $(57.14 \%)$ over 60 females $(42.86 \%)$. (TABLE 2$)$

A total of 140 throat (tonsillar surface) swabs were cultured, out of which 135 cultures (96.43\%) were positive, 3 swabs (2.14\%) showed no growth and 2 swabs (1.43\%) showed contamination.

More than one bacterial strains were isolated from 135 positive culture swabs suggesting polymicrobial nature of bacterial flora in patients of tonsillitis. Streptococcus viridians (SV) group and Branhmellacatarrhalis (BC) were isolated from 100 swabs $(71.43 \%)$ which are considered as the normal bacterial flora of the throat.

Along with Streptococcus viridians (SV) group and Branhmellacatarrhalis (BC) in decreasing order of frequency Staphylococcus aureus was isolated from 16 swabs (11.43\%), followed by Streptococcus pneumoniae from 7 swabs (5.00\%), Pseudomonas and E. coli from 4 swabs (2.86\%) each, beta haemolyticStreptococci 3 swabs (2.14\%) and Proteus vulgaris 1 swab (0.71\%). (TABLE 3)

Antibiotic sensitivity pattern

A total of 11 types of antibiotics were selected to test the susceptibility of the isolated bacteria which are ampicillin, erythromycin, ciprofloxacin, cotrimoxazole, tetracycline, chloramphenicol, cefaclor, gentamicin, tobramycin, netilmycin and vancomycin.

Analyzing sensitivity pattern of 16 isolates of Staphylococcusspecies, sensitivity of $81.25 \%$ with netilmycin, $68.75 \%$ with gentamicin and $62.50 \%$ with erythromycin and ciprofloxacin was observed. $100 \%$ resistance with chloramphenicol and cefeclor , $81.25 \%$ with tetracycline and tobramycin and $68.75 \%$ with ampicilline and cotrimoxazole was found against Staphylococcus spp. Out of the 16 isolates, $6(37.50 \%)$ were methicillin resistant Staphylococcus aureus (MRSA). which were found 100\% sensitive to Vancomycin.

Beta haemolyticstreptococci were found $100 \%$ sensitive with netilmycin, chloramphenicol, gentamicin, tobramycin, tetracycline and erythromycin. $66.67 \%$ strains of beta haemolyticstreptococci were resistant to cotrimoxazole\&cefaclor while $33.33 \%$ were resistant to ampicilline\& ciprofloxacin.

Proteus species were found $100.00 \%$ sensitive to netilmycin and resistant with all other antibiotics.

E. coli were $100.00 \%$ sensitive with netilmycin and gentamicin and $50.00 \%$ with cefaclor and ciprofloxacin. It was $100.00 \%$ resistant with ampicilline while $75.00 \%$ resistance with cotrimoxazole, tetracycline, tobramycin and chloramphenicol was observed.

Pseudomonas species were found $100.00 \%$ sensitive with netilmycin and ciprofloxacin and $50.00 \%$ sensitive with gentamicin. It was $100.00 \%$ resistant with ampicilline, cotrimoxazole while $75.00 \%$ resistance with chloramphenicol, tetracycline and tobramycin was observed.

Pneumococcus species were found $100.00 \%$ resistant with cefaclor, $85.71 \%$ with gentamicin, and $71.43 \%$ with tobramycin. This was $57.14 \%$ resistant with erythromycin, ampicilline, cotrimoxazole and tetracycline. $71.43 \%$ sensitivity with netilmycin and chloramphenicol and $57.14 \%$ with ciprofloxacin was found in this study.

\section{Discussions}

Tonsillitis is a common disease in children and it is not uncommon for a child to have at least one or more episodes of acute tonsillitis each year, particularly in pre-school or primary school age group. The child may present with sore throat, difficulty in swallowing, fever, general malaise and history of upper respiratory tract infection.

In our study, the commonest age group of tonsillitis is between 11-20 years, where the maximum number of 57 cases $(40.71 \%)$ occurred. In a study patient's age group having tonsillitis was 2.5 to 17 years (mean 6 years $)^{[5]}$.

Streptococcus viridians andBranhmellacatarrhalis were isolated in $71.43 \%$ in our study, which are considered as the normal flora in pharynx. Gaffeny et al $(1991)^{[6]}$ reported that in core swabs mixed pathogens were isolated in most cases (48.0\%) with commonest mixture being alpha haemolyticStreptococci, H. influenza and S. aureus. Brooke et al $(1981)^{[5]}$ found the polymicrobial anaerobic and aerobic nature of deep tonsillar flora in children with recurrent tonsillitis and demonstrated the presence of many beta-lactamase-producing organisms in $74 \%$ of the patients. In our study $57.14 \%$ organisms causing tonsillitis were beta lactamase producing organisms. 
Isolation of beta haemolyticstreptococci was less in our study $(2.22 \%)$ as compare to $48.72 \%$ in the study by Sadoh et al (2008) $)^{[7]}, 23 \%$ in the study by Loganthan et al (2006) ${ }^{[8]}$ and $30 \%$ in study by Ozek et al $(1967)^{[9]}$.

Opposed to our present findings in which incidence of Staphylococcus aureus (11.85\%) and Streptococcuspneumoniae $(5.18 \%)$, in study by Loganathan et al $(2006){ }^{[8]}$ Staphylococcus aureus $(40.9 \%)$ was the commonest bacterial isolate in recurrent tonsillitis and $26 \% \mathrm{~S}$. aureus were the commonest isolate on throat swab culture in another study by Jha et al $(2008)^{[10]}$.

Gaffeny et al (1991) ${ }^{[6]}$ reported that Haemophillusinfluenza was most common isolate from the tonsillar core followed by $S$. aureus, which is contrary to our finding in which $H$. influenza was not isolated.

It is known that the chronically inflamed tonsillar tissue contains more scar tissue after each infection causing an impairment of antibiotic penetrability into their core and more resistance (Brook et al, 1984) ${ }^{[11]}$. Antibiotic resistance among bacteria varies between different geographical areas even within the same country $(\text { Lim, 2003) })^{[12]}$

Staphylococcus aureus showed $62.50 \%$ susceptibility to ciprofloxacin which is in concordance with the finding of $64.1 \%$ sensitivity in study by Hawan $(2000)^{[13]}$ while sensitivity of $98.98 \%$ was in study by Eldeeb et al $(2006)^{[14]}$. Sensitivity of $81.25 \%$ with netilmycin makes it better choice in S. aureus infection.

Beta haemolyticStreptpcocci were $100.00 \%$ sensitive to netilmycin, erythromycin, chloramphenicol, tetracycline. El-Daly et al (1990) ${ }^{[15]}$ observed that beta haemolyticstreptococci showed $25 \%$ sensitivity to erythromycin, chloramphenicol and tetracycline respectively. Higher activity of $73 \%$ for erythromycin and $90 \%$ for ciprofloxacin was reported by Baquero et al (1999) ${ }^{[16]}$.

E. coli were $100.00 \%$ sensitive with netilmycin and gentamicin and $50.00 \%$ with cefaclor and ciprofloxacin.Oteo et al (2002) ${ }^{[17]}$ reported $82.81 \%$ sensitivity for ciprofloxacin and $93.61 \%$ sensitivity for gentamicin which was similar with finding of $85.71 \%$ and $78.57 \%$ sensitivity for ciprofloxacin and gentamicin respectively in study of Eldeeb et al (2006) ${ }^{[14]}$.

Pseudomonas species were found $100.00 \%$ sensitive with netilmycin and ciprofloxacin and $50.00 \%$ sensitive with gentamicin. $100.00 \%$ sensitivity with ciprofloxacin is in agreement with the finding by Gebreel et al (2000) ${ }^{[18]}$ and Eldeeb et al (2006) ${ }^{[14]}$. 100.00\% resistant with ampicilline, cotrimoxazole and $75.00 \%$ resistance with chloramphenicol, tetracycline and tobramycin was observed in our study. Higher sensitivity of $94.28 \%$ with gentamicin and lower sensitivity of $17.14 \%$ with tetracycline and $11.43 \%$ with chloramphenicol was reported in the study by Eldeeb et al (2006) ${ }^{[14]}$.

Streptococcus pneumoniae showed $71.43 \%$ sensitivity with netilmycine and chloramphenicol and $57.14 \%$ with ciprofloxacin in this study. Higher sensitivity of $90 \%$ and $94.74 \%$ with ciprofloxacin was reported by Eldeeb et al(2006) ${ }^{[14]}$ and Hawan et al $(2000)^{[13]}$.

\section{Figures And Tables}

Table 1: Age distribution of Tonsillitis Patients

\begin{tabular}{|l|l|l|l|}
\hline S.No. & Age group (years) & No of Cases & Percentage \\
\hline 1 & $0-10$ & 26 & 18.57 \\
\hline 2 & $11-20$ & 57 & 40.72 \\
\hline 3 & $21-30$ & 45 & 32.14 \\
\hline 4 & $>30$ & 12 & 8.57 \\
\hline & TOTAL & 140 & 100 \\
\hline
\end{tabular}

Table 2: Sex- wise prevalence of Tonsillitis

\begin{tabular}{|l|l|l|}
\hline Sex & Number (140) & Percentage \\
\hline Male & 80 & 57.14 \\
\hline Female & 60 & 42.86 \\
\hline
\end{tabular}

Table 3: Bacterial isolates from tonsillar swabs

\begin{tabular}{|c|c|c|c|}
\hline S.No. & Bacterial isolates & No of Isolates & $\%$ \\
\hline 1 & $\begin{array}{l}\text { Streptococcus viridans }(S V), \\
\text { Branhamellacatarrhalis }(B C)\end{array}$ & 100 & 71.43 \\
\hline 2 & $\begin{array}{l}\text { Streptococcus viridans }(S V), \\
\text { Branhamellacatarrhalis }(B C) \\
\text { Staphylococcus } \text { species }\end{array}$ & 16 & 11.43 \\
\hline 3 & $\begin{array}{l}\text { Streptococcus viridans }(S V), \\
\text { Brahamellacatarrhalis }(B C) \\
\text { Streptococcus pneumoniae }(S P)\end{array}$ & 7 & 5.00 \\
\hline 4 & $\begin{array}{l}\text { Streptococcus viridans }(S V), \\
\text { Branhamellacatarrhalis }(B C) \\
\text { Pseudomonas aeruginosa }\end{array}$ & 4 & 2.86 \\
\hline 5 & $\begin{array}{l}\text { Streptococcus viridans }(S V), \\
\text { Branhamellacatarrhalis }(B C)\end{array}$ & 4 & 2.86 \\
\hline
\end{tabular}




\begin{tabular}{|l|l|l|l|}
\hline & E.Coli & & \\
\hline 6 & $\begin{array}{l}\text { Streptococcus viridans }(\text { SV), } \\
\text { Branhamellacatarrhalis }(B C) \\
\text { Beta hemolytic Streptococcus }\end{array}$ & 3 & 2.14 \\
\hline 7 & $\begin{array}{l}\text { Streptococcus viridans }(\text { SV), } \\
\text { Branhamellacatarrhalis }(B C) \\
\text { Proteus species }\end{array}$ & 1 & 0.71 \\
\hline 8 & Sterile/Contaminated & 5 & 3.57 \\
\hline Total & & 140 & 100 \\
\hline
\end{tabular}

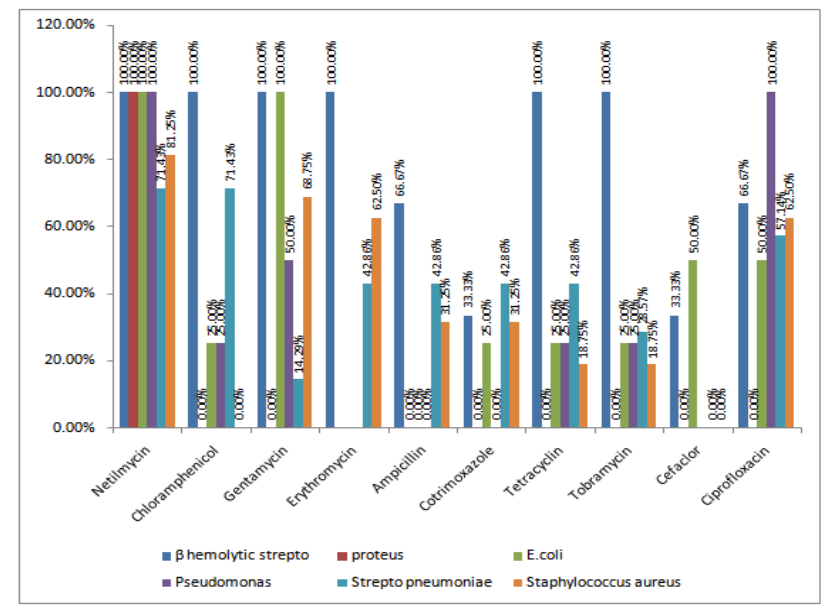

Fig 1: Antibiotic sensitivity pattern of different bacterial isolates

\section{Conclusion}

The commonest age group of tonsillitis is between 11-20 years and the minimum beyond 30 years.

Bacterial isolates from throat swabs showed Streptococcus viridians (SV) and Branhamellacatarrhalis $(\mathrm{BC})$ as the part of polymicrobial flora in the throat. Along with them Staphylococcus aureus was commonest isolate followed by Streptococcus pneumonae, Pseudomonas, E coli, beta haemolytic Streptococci and Proteus vulgaris.

Antibiotic sensitivity pattern of pathogens from throat swab revealed that the antibiotic to which most organisms were sensitive was netilmycin 30 strains $(85.71 \%)$, ciprofloxacin 22 strains $(62.86 \%)$, gentamicin 21 strains $(60 \%)$, erythromycin 16 strains $(45.71 \%)$, tetracyclines 11 strain $(31.43 \%)$, chloramphenicol 10 strains (28.57\%), cotrimoxazole 10 strains (28.57\%), ampicillin 10 strains (28.57\%), tobramycin 10 strains $(28.57 \%)$, and cefaclor 3 strains $(8.57 \%)$.

Identification of bacterial isolates in tonsillitis and their antibiotic sensitivity pattern could revolutionize the management of chronic tonsillitis.

\section{References}

[1] Brook I, Foote PA. Comparision ofthemicrobiology of recurrent tonsillitis between children and adults. Laryngoscope,96(12), 1986, 1385-8.

[2] Robert. MD, Lawrence W. Microorganisms isolated from peritonsillar abscess and recurrent tonsillitis. NewYork, San Francisco, London: Academic Press;.1988, p. 126-31.

[3] Upal K, Bias AS. Tonsillarmicroflora-superficial surface vs deep, J Laryngol. Otol. 103, 1989, 175-7.

[4] Usamah H, Michel E, Marwan U, Nabil F, Ghassan M. Characteristics of pathogens recovered from the tonsils and adenoids in a group of Lebanese children undergoing tonsillectomy and adenoidectomy. J. Appl. Res. 5(3), 2005, 473-80.

[5] Brook I, Yocum P, Friedman EM. Anaerobic and aerobic bacteria in tonsils of children with recurrent tonsillitis. Ann OtolRhinolLaryngol. May-June- 90(3 Pt 1), 1981, 261-3.

[6] Gaffney RJ, Freeman DJ, Walsh MA, Cafferkey MT. Differences in tonsil core bacteriology in adults and children: A prospective study of 262 patients. Respir. Med. 85, 1991, 383-8.

[7] Sadoh WE, Sadoh AE J, Oladipo AO, Okunola OO. Bacterial isolates of tonsillitis and pharyngitis in a paediatric casualty setting. J Med Biomed Research- 7, 2008, 5-11.

[8] Loganthan A, Arumainathan U D, Raman R. Comparative study of bacteriology in recurrent tonsillitis among children and adults. Singapore medical journal-47(4), 2006, 271-5.

[9] Ozek O, Egilmcz S, Ang O, Savas I. A bacteriological study of chronic tonsillitis. ActaOtoLaryngologica; 63, 1967, 455-61.

[10] Jha AK, Sharma S. Patients with tonsil problems at NMCTH - a report. Nepal Med Coll J, 10(4), 2008, 258-9.

[11] Brook I, Yocum P. Bacteriology of chronic tonsillitis in young adults. Archives of Otolaryngology, 110(12), 1984, 803-5.

[12] Lim V. Antibiotic resistance in the Community. Med. J. Malaysia, 58(2), 2003, 156-8.

[13] Hawan , SM. Lower respiratory tract infection among critically ill patients in Alexandria [thesis]. Alexandria: Alrexandria University. 2000. 
[14] Eldeeb AH, Khashan EM. Microbiological study on respiratory tract infections in Libya. The Egyptian Journal of Hospital Medicine, 24, 2006, 442-59.

[15] El-Daly OM, Shaheen AAM, Wegd-an AA, Abdel-Azim M, Rashad AM and El-Shewy ME. Recurrent suppurative otitis media is it a new infection or relapse? Az. J. Microbiol, 7, 1990, 261-70.

[16] Baquero F, Rodriguez JA, Lomas JD the Spanish surveillance group for respiratory pathogen. Antimicrobial resistance of 914 beta haemolytic streptococci isolated from pharyngeal swabs in Spain. Antimicrob Agents Chemother, 43, 1999, 178-80.

[17] Oteo J, Campos J, and Baquero F. Antibiotic resistance in 1962 invasive isolates of Escherichia coli in 27 Spanish hospitals participating in the Europian Antimicrobial resistance Surveillence System. J. Antimicrob. Chemother, 50, 2002, 945-52.

[18] Gebreel HM, Abu-Shady MR, MoustafaEA, and Mohamed WF. Incidence of surgical wound infection after cardiac and thoracic surgery. Az. J. Microbiol, 48, 2000, 7-18. 